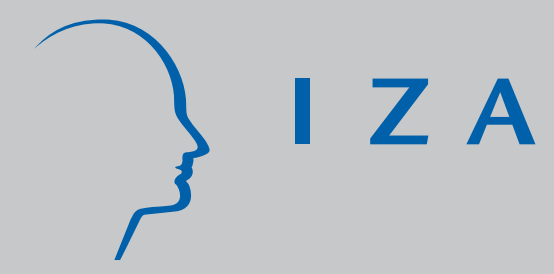

IZADP No. 3109

Family Bargaining and Taxes:

A Prolegomenon to the Analysis of J oint Taxation

Robert A. Pollak

October 2007 


\title{
Family Bargaining and Taxes: A Prolegomenon to the Analysis of Joint Taxation
}

\author{
Robert A. Pollak \\ Washington University in St. Louis, \\ NBER, CESifo and IZA
}

Discussion Paper No. 3109

October 2007

\author{
IZA \\ P.O. Box 7240 \\ 53072 Bonn \\ Germany \\ Phone: +49-228-3894-0 \\ Fax: +49-228-3894-180 \\ E-mail: iza@iza.org
}

\begin{abstract}
Any opinions expressed here are those of the author(s) and not those of the institute. Research disseminated by IZA may include views on policy, but the institute itself takes no institutional policy positions.

The Institute for the Study of Labor (IZA) in Bonn is a local and virtual international research center and a place of communication between science, politics and business. IZA is an independent nonprofit company supported by Deutsche Post World Net. The center is associated with the University of Bonn and offers a stimulating research environment through its research networks, research support, and visitors and doctoral programs. IZA engages in (i) original and internationally competitive research in all fields of labor economics, (ii) development of policy concepts, and (iii) dissemination of research results and concepts to the interested public.
\end{abstract}

IZA Discussion Papers often represent preliminary work and are circulated to encourage discussion. Citation of such a paper should account for its provisional character. A revised version may be available directly from the author. 


\section{ABSTRACT \\ Family Bargaining and Taxes: A Prolegomenon to the Analysis of Joint Taxation}

Does joint taxation disadvantage women? To answer that question, this paper begins by reviewing unitary and bargaining models of intrafamily allocation, and then discusses the determinants of "bargaining power" in a world without taxes. It argues that wage rates rather than earnings are determinants of bargaining power, and then argues that productivity in household production is also a source of bargaining power. In the absence of human capital effects, joint taxation does not appear to disadvantage women in either divorce threat or separate spheres bargaining. Hence, the claim that joint taxation disadvantages women, if it is correct, depends on effects that operate through the incentives to accumulate human capital. But a satisfactory analysis of the effects of taxation on human capital awaits the further development of dynamic models of family bargaining.

JEL Classification: $\quad H 21, H 24, D 13, J 22$

Keywords: joint taxation, family bargaining, household production

Corresponding author:

Robert A. Pollak

Washington University in St. Louis

Faculty of Arts and Sciences and the Olin Business School

Campus Box 1133

1 Brookings Drive

St. Louis, MO 63130-4899

USA

E-mail:pollak@wustl.edu

\footnotetext{
* An earlier version was presented at the CESifo workshop on Taxation and the Family in Venice, 2426 July 2003. Much of the material on earnings, wage rates and household production is drawn from Pollak [2005]. I am grateful to Saku Aura, Paula England, Elisabeth Gugl, Joanne Spitz and Nancy Staudt for helpful comments and to the John D. and Catherine T. MacArthur Foundation for their support. The usual disclaimer applies.
} 


\section{Introduction}

Does joint taxation disadvantage women? In Taxing Women McCaffery [1997] argues that joint taxation disadvantages women in family bargaining and disadvantages women in the event of divorce. With joint taxation (also known as joint filing), a married couple's tax liability depends on the sum of their incomes. With individual taxation (also known as separate filing), each spouse's taxes depend on his or her individual income but is independent of the income of the other spouse. The U.S. income tax is based on joint taxation, while most European countries rely on individual taxation. ${ }^{1}$ McCaffery argues that with joint taxation "secondary earners," generally but not necessarily wives, face high marginal tax rates that reduce their labor force participation and their hours of work. Is this argument correct and, if it is, does it imply that joint taxation disadvantages women in family bargaining?

Economists traditionally emphasize the effects of taxation on labor supply and labor force participation. This emphasis is usually in the context of a "unitary model" in which married couples maximize a family utility function subject to a family budget constraint. Apps and Rees, in a series of papers, have argued persuasively that to analyze the effect of taxation we must recognize not only market work and leisure, but also household production. ${ }^{2}$ Neither the traditional literature on the effects of taxation on labor supply nor the work of Apps and Rees emphasizing household production confront the intrafamily allocation issues raised by bargaining models of marriage. The earliest bargaining models of marriage -- the divorce threat models of Manser and Brown [1980]

\footnotetext{
${ }^{1}$ Alm and Melnik [2005] and Messere [1998] provide useful surveys of the tax systems in industrialized countries.

${ }^{2}$ For a summary of and references to their work, see Apps and Rees [2007].
} 
and McElroy and Horney [1981] -- investigated labor supply but ignored household production and taxes. More recent bargaining models, such as the separate spheres model of Lundberg and Pollak [1993], emphasize the role of nonlabor income but ignore wage rates.

In this paper I argue that wage rates rather than earnings determine bargaining power in the separate spheres model. Those who treat earnings as an indicator of bargaining power typically make two mistakes. First, they assume that earnings at the observed bargaining equilibrium are a good indicator of earnings at the unobserved threat point. Second, they assume that earnings at the threat point are a good indicator of wellbeing at the threat point. Neither assumption is justified. A spouse whose earnings are high because he or she chooses to allocate more hours to market work, and correspondingly less hours to household production and leisure, does not have more bargaining power. But a spouse whose earnings are high because of a high wage rate does have more bargaining power.

The effects of joint taxation differ in divorce threat and separate spheres bargaining. In divorce threat bargaining, the threat point depends on the well-being of the spouses in the event of divorce, and thus depends on the tax schedule faced by divorced individuals. In separate spheres bargaining, the threat point is internal to the marriage and depends on the noncooperative game that defines the internal threat point. If this noncooperative game requires spouses to make labor supply decisions, then their wage rates are the key determinants of the threat point and, hence, of bargaining power.

With joint taxation the analysis of the separate spheres noncooperative game requires a specification of the tax implications of alternative labor-force participation 
decisions. I argue that a default tax schedule (e.g., "married, filing separately") that depends only on each spouse's individual earnings provides the required specification. Such a default tax schedule enables spouses to calculate their well-being in the noncooperative equilibrium which is the threat point.

Section 1 discusses both unitary and bargaining models of intrafamily allocation. Section 2 discusses the meaning of "bargaining power," first considering the roles of nonlabor income and wage rates, and then extending the analysis to household production. These two sections constitute a prolegomenon to the analysis of taxation. In section 3 I turn to tax systems, distinguishing between joint and individual taxation of married couples. Section 4 examines the role of taxes in bargaining models, arguing that a default tax schedule is required to calculate the noncooperative equilibrium that is the threat point in separate spheres bargaining. Section 5 discusses various extensions that deserve more attention. Section 6 is a brief conclusion.

\section{Intrafamily Allocation}

Economists' traditional models of family behavior are "unitary" -- families are assumed to maximize a utility function subject to a budget constraint. Samuelson [1956], in a throw-away section in his classic paper on "Social Indifference Curves," identified the problem with unitary models. The "Dr. Jekyll and Mrs. Jekyll" problem, as Samuelson called it, arises because individuals within families have preferences, and aggregating individuals' preferences into family preferences is a social choice problem subject to the difficulties identified and analyzed by Arrow [1950, 1951]. 
Intrafamily allocation models can be grouped into four classes, some containing numerous subclasses. The first class consists of three models proposed by Gary Becker, two of which imply that families behave as if they were maximizing a family utility function subject to a family budget constraint. The second class contains Chiappori's "collective model" and its generalizations. Chiappori assumes that family behavior is efficient, but he does not assume that the family maximizes a utility function, nor does he specify a particular model of family bargaining. The third class consists of cooperative bargaining models. Following the pioneering work of Manser and Brown [1980] and of McElroy and Horney [1981] in the early 1980s, cooperative bargaining models have come to play a central role in the analysis of family behavior. The fourth and final class, noncooperative bargaining models, are playing an increasing role in family economics; unlike cooperative bargaining models, noncooperative bargaining models accommodate the possibility that at least some families sometimes behave inefficiently.

\subsection{Becker's Models of Intrafamily Allocation}

Becker's Treatise on the Family [1981; enlarged ed, 1991] offers three distinct models of intrafamily allocation; I provide an abbreviated discussion here and an extended discussion in Pollak [2003]. In Becker's altruist model, one family member -characterized in Pollak [1988] as the "husband-father-dictator-patriarch" and in Pollak [2003] as a "quasi-dictator" -- maximizes his utility subject to the family's resource constraint and to the participation constraint that no family member be worse off than he or she would be outside the family. Becker assumes that the altruist derives some utility from the utility of other family members, so maximizing the altruist's utility need not drive other family members to their reservation utility levels. The altruist model is 
observationally equivalent to an "ultimatum game" in which the altruist is the proposer who can confront other family members with take-it-or-leave-it choices.

Becker's analysis of the marriage market rests on an entirely different model of intrafamily allocation. Becker's marriage market model assumes that prospective spouses can make binding agreements regarding allocation within marriage. Thus, allocation within marriage implements agreements made in the marriage market, leaving no scope for bargaining within marriage. The standard "individual rationality" assumption implies that no prospective spouse would agree to accept less than he or she would receive in the next best marriage. These two assumptions rule out bargaining within marriage, and imply that allocation within marriage is determined in the marriage market, either by competition or by bargaining between prospective spouses. If Becker's marriage market contains a large number of men and women; if men and women meet prospective spouses with high frequency; and if the marriage market is dense in the sense that (i) for each man, there are many similar men and (ii) for each woman, there are many similar women; then competition rather than bargaining in the marriage market determines intrafamily allocation.

Becker's third model assumes that intrafamily allocation is efficient but does not specify a particular model of intrafamily allocation. This Coasian efficiency assumption is especially powerful in conjunction with additional assumptions (e.g., transferrable utility) that allow the separation of household production from consumption. Together, these assumptions enable Becker to analyze household production independently of intrafamily allocation. 


\subsection{Chiappori's Collective Model}

Chiappori's collective model, Chiappori [1988, 1992], characterizes intrafamily allocation by a single-valued, Pareto-efficient "sharing rule" that is assumed to satisfy certain regularity conditions. The sharing rule can be regarded as the reduced form of an unspecified bargaining model. As such, it provides a convenient device for bracketing the discussion of intrafamily allocation in order to focus on other issues. For example, Lundberg and Pollak [2003] use the sharing rule in this way in their discussion of the two-earner couple location problem and Pezzin, Pollak, and Schone [2007] use it in their discussion of the provision of long-term care by adult children for disabled elderly parents. In both cases, intrafamily allocation is modeled as a two-stage game in which the second-stage subgame is not specified, but whose solution is described by a singlevalued Pareto-efficient sharing rule.

The assumption that family behavior can be characterized by a Pareto-efficient sharing rule, although it has important advantages, has two significant limitations. First, because the collective model does not specify a particular bargaining model or class of bargaining models, it offers no guidance for choosing which variables to include in the sharing rule as determinants of bargaining power. Second, as Lundberg and Pollak [2003] argue, unless family members can make binding agreements, the assumption that bargaining outcomes are efficient is implausible for major decisions that affect future bargaining power.

\subsection{Cooperative Bargaining Models}

Cooperative bargaining models in general, and the Nash bargaining model in particular, have become the standard tool for analyzing intrafamily allocation. I begin 
with a version of the Nash bargaining model with three components: (i) a feasible set in the utility space, (ii) reservation utilities for each family member, and (iii) a "threat point" that reflects family members' bargaining power. In the original Nash bargaining model, Nash [1950], the reservation utilities and the threat point coincide. In virtually all bargaining models of marriage, reservation utilities are assumed to correspond to divorce. If the reservation utility constraints are not binding, then modified Nash bargaining implies an allocation that maximizes the product of the gains to cooperation, measured in utility, subject to the family's resource constraint. More precisely, the Nash product function is given by: $\mathrm{N}=\left(\mathrm{U}^{\mathrm{h}}-\mathrm{U}^{* \mathrm{~h}}\right)\left(\mathrm{U}^{\mathrm{w}}-\mathrm{U}^{* \mathrm{w}}\right)$, where $\mathrm{U}^{\mathrm{h}}$ and $\mathrm{U}^{\mathrm{w}}$ denote the utilities of the husband and wife and $\left(\mathrm{U}^{* \mathrm{~h}}, \mathrm{U}^{* \mathrm{w}}\right)$ is the threat point. Figure 1 illustrates the Nash bargaining model when the reservation utility constraints are not binding.

In the bargaining models of marriage originally proposed by Manser and Brown [1980] and by McElroy and Horney [1981] the threat point and the reservation utilities coincide with each other and correspond to the utility of divorce. Thus, the threat point in these models is external to the marriage. In contrast, in the "separate spheres" model of Lundberg and Pollak [1993], the threat point is internal to the marriage and corresponds to a "noncooperative marriage." Lundberg and Pollak model the noncooperative marriage as a voluntary contribution game in which spouses allocate some of their resources to provide household public goods. ${ }^{3}$ Bergstrom [1996] characterizes the noncooperative marriage as "harsh words and burnt toast."

Compared with divorce threat models, separate spheres models have two advantages. First, even in societies that allow divorce, the threat of divorce may not be

\footnotetext{
${ }^{3}$ Woolley [1988] appears to have been first to use a noncooperative Cournot-Nash equilibrium within marriage as the threat point in a bargaining model.
} 


\section{Figure 1}

\section{The Nash Bargaining Solution}

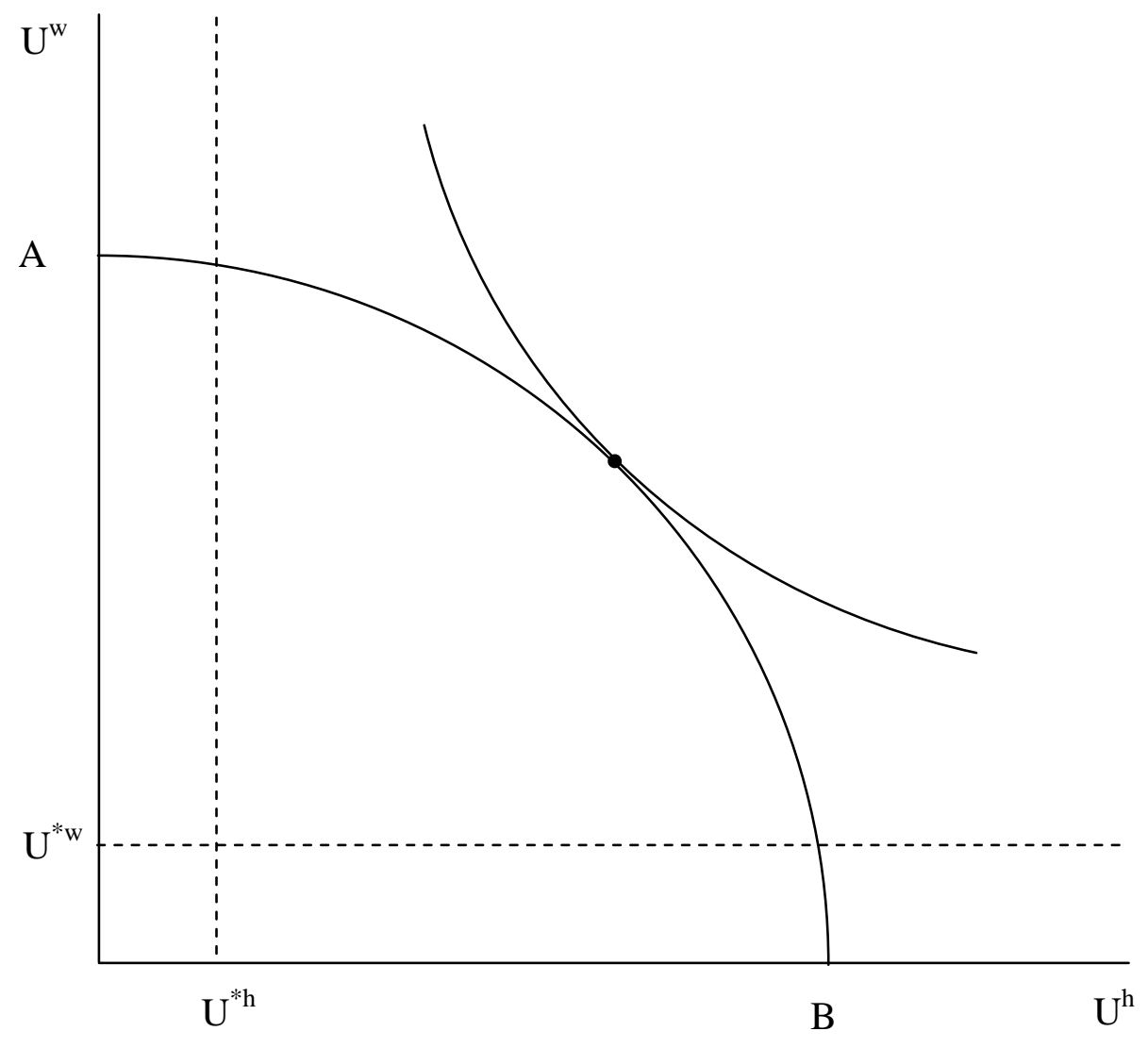


credible: everyday issues such as which television program to watch and what to have for dinner seem unlikely to be resolved by divorce threat bargaining. Second, in some societies that allow divorce, it is so rare that it is implausible that the threat of divorce is a primary determinant of allocation within marriage. For example, according to Stone [1990, Table 13.1], even after the 1857 Divorce Act which substantially liberalized divorce law in England and Wales, the number of divorces per year remained under 1000 until the First World War. ${ }^{4}$

In a society that forbids divorce, the divorce threat model provides no insight into allocation in marriage. In a society in which couples have limited access to divorce, such as England and Wales before the First World War, the divorce threat model provides very limited insight into allocation in marriage. Even in a society in which divorce is readily available and the divorce threat model describes allocation in many marriages, alternative models may provide a better description of allocation in other marriages.

Bargaining models of marriage have emphasized Nash bargaining and neglected other cooperative bargaining models and solution concepts. For example, although Manser and Brown considered both the Nash and the Kalai-Smorodinsky [1975] bargaining solutions, subsequent work on bargaining in families has virtually ignored Kalai-Smorodinsky. Gugl [2004] provides an interesting exception, considering both the Nash and Kalai-Smorodinsky bargaining solutions. Her work suggests that the difficulty of doing comparative statics with Kalai-Smorodinsky may account for its eclipse by the Nash bargaining solution. The generalized Nash bargaining solution -- a solution concept

\footnotetext{
${ }^{4}$ The population of England and Wales in 1911, three years before the First World War, was approximately 36 million.
} 
that does not impose Nash's symmetry axiom -- has also received little attention. ${ }^{5}$ The core, despite its prominence in game theory, has received almost no attention as a solution concept in the economics of the family, perhaps because it does not yield a unique solution in two-person games. ${ }^{6}$

\subsection{Noncooperative Bargaining Models}

Noncooperative bargaining models assume that family members are restricted to self-enforcing agreements -- agreements that self-interested family members would choose to implement. Cooperative bargaining models, in contrast, assume that all agreements are enforceable and thus place no restrictions on the agreements that family members can reach. Cooperative models assume that bargaining always leads to Paretoefficient outcomes and, hence, cooperative models can shed no light on the conditions that lead to efficiency. Indeed, the most serious drawback of cooperative bargaining models is their inability to investigate the conditions that determine whether bargaining will lead to efficient outcomes. Noncooperative bargaining models, because they can generate inefficient as well as efficient outcomes, enable us to investigate efficiency.

The threshold difficulty in using noncooperative game theory to model family interactions is the absence of formal rules. In contrast to tightly-structured interactions such as auctions or alternating-offer games, family bargaining exemplifies the class of "...complex, loosely-structured social interaction," a phrase I have borrowed from Shubik [1989]. Shubik's concern is the general problem of using noncooperative game theory to model interactions that lack formal structure, not the specific problem of modeling family

\footnotetext{
${ }^{5}$ Nash's axioms are Pareto efficiency, invariance to linear transformation of individuals' von NeumannMorgenstern utility functions, symmetry (i.e., interchanging the labels on the players has no effect on the solution), and a contraction consistency condition.

${ }^{6} \mathrm{~A}$ further difficulty with the core is that in games with more than two players it may be empty.
} 
interactions. Shubik's point is that we can avoid the need to specify the rules by modeling complex, loosely-structured social interactions as cooperative games. A major objection to using cooperative game theory to sidestep the difficulty of specifying the rules of the game -- an objection Shubik ignores -- is that cooperative game theory assumes Pareto efficiency.

Noncooperative game theory also leads to difficulties. The threshold difficulty is specifying family interactions as a particular game from the lengthy menu offered by noncooperative game theory. One-shot games are familiar and easy to analyze: some have only inefficient equilibria, others have only efficient equilibria, and still others have both inefficient and efficient equilibria. Multiple equilibria raise the issue of equilibrium selection. But apart from illustrating these well-known possibilities, one-shot games teach us little about ongoing family interactions.

Repeated games -- games in which the same "stage game" is played over and over again -- are more promising. The folk theorem asserts that if the players are sufficiently patient, then all feasible, individually-rational allocations are subgame perfect equilibria of the repeated game. That is, repeated games typically have very large solution sets and, if players are sufficiently patient, such games have many Pareto-efficient equilibria as well as many Pareto-inefficient equilibria. Thus, unless we are willing to tolerate very large solution sets, equilibrium selection becomes the crucial issue. If we accept the Coasian assumption that bargaining leads to Pareto-efficient outcomes and if we assume that the Pareto-efficient equilibrium is unique, we are close to Chiappori's single-valued, Pareto-efficient sharing rule. Alternatively, we might argue that cooperative bargaining models provide a framework for analyzing which efficient outcome will be selected. But 
even this does not argue for a particular solution concept such as the Nash bargaining solution. In the context of bargaining in marriage, Lundberg and Pollak [1994] consider a repeated game in a stationary environment -- the voluntary contribution game is the stage game which is played over and over. For many everyday issues -- which television program to watch, what to have for dinner -- repeated games provide plausible models. Repeated games, however, do not provide satisfactory models for major issues whose resolution will affect future bargaining power.

For big, up-front decisions that affect future bargaining power, two-stage models are both plausible and tractable. For example, Lundberg and Pollak [2003] analyze the "two-earner couple location game." The first stage determines whether the couple remains together and, if they do, determines their location; the second stage determines allocation within marriage. This second-stage allocation is assumed to be "conditionally efficient," that is, efficient given the location determined in the first stage. Distribution in the second stage depends on bargaining power, and bargaining power depends on the location chosen in the first stage. The crucial assumption is that at the first stage family members cannot commit themselves to refrain from exploiting bargaining advantages they gain from the first-stage decision. Lundberg and Pollak show that, when the spouses cannot make binding commitments, the first-stage decision may be an inefficient location or an inefficient divorce.

Two-stage games are not necessarily two period games. For example, the twoearner couple location game analyzed by Lundberg and Pollak consists of a first-stage noncooperative game that, for some first-stage moves, leads to a repeated game. More specifically, the repeated game arises if the husband and wife decide to remain together, 
either at the original location or at a new location. Although the second-stage game can be interpreted as the reduced form of a repeated game, Lundberg and Pollak finesse the specification of the second-stage game by assuming that it has a unique, Pareto-efficient solution and invoking a Chiappori sharing rule.

Two-stage games are also analyzed by Konrad and Lommerud [2000], by Lundberg [2002], and by Pezzin, Pollak, and Schone [2007]. In Konrad and Lommerud, potential spouses overinvest in education at first stage to gain a bargaining advantage in the second stage. Lundberg [2002] analyzes a game in which earnings in the first stage determine bargaining power in the second. In the context of bargaining in families, in contrast to bargaining in marriage, Pezzin, Pollak, and Schone [2007] model interactions among adult children who bargain about caring for a disabled elderly parent. The first stage determines living arrangements (e.g., which child coresides with the parent, or whether the parent lives in a nursing home). The second stage determines intrafamily transfers. Pezzin, Pollak, and Schone assume it is common knowledge that the secondstage allocation is conditionally Pareto efficient (i.e., Pareto efficient given the living arrangement determined in the first stage). Even with this assumption, however, the equilibrium of the two-stage game need not be Pareto efficient: the living arrangement is a big up-front decision that affects future bargaining power (e.g., of the child who lives with the parent vis-à-vis the other children), and the children cannot (or will not) make binding agreements. For example, if the child who coresides with the disabled elderly parent will be disadvantaged in future bargaining with her siblings, then no child may be willing to co-reside with the parent. As a result, the parent may move into a nursing home, even though she and all of the children would prefer that she live with one of the 
children with all of the other children making side payments to support that living arrangement. In the absence of binding agreements, however, coresidence with an adult child may not be an equilibrium -- indeed, the nursing home may be the unique equilibrium of the two-stage game even though it is Pareto inefficient.

Three examples illustrate the wide range of potential applications of two-stage games when binding agreements are not feasible and big up-front decisions affect future bargaining power. (i) Human capital investments, whether made before or during marriage, increase wage rates and thus affect bargaining power within marriage. Under a wide range of assumptions, this can lead to inefficient investment in human capital. (ii) Marriage itself is a big, up-front decision that affects future bargaining power. Unless we follow Becker's marriage market model and assume that prospective spouses can make binding agreements regarding allocation within marriage, inefficient matching or inefficient nonmatching may occur in the marriage market equilibrium. Lundberg and Pollak [1993] analyze a simple marriage-market model that illustrates this possibility. (iii) Fertility is also a big, up-front decision that affects future bargaining power. A husband's promise to share equally in child care is unenforceable and, recognizing this, a couple may have fewer children than both spouses would prefer.

In dynamic games, actions in each period affect bargaining power in subsequent periods. ${ }^{7}$ Thus, two-stage games are the simplest dynamic games. ${ }^{8}$ In repeated games, actions in one period have no effect on bargaining power in subsequent periods, so repeated games are not dynamic games. A human capital example clarifies the distinction between two-stage games and other dynamic games. A dynamic game is

\footnotetext{
${ }^{7}$ Aura [2007] and Lich-Tyler [2004] analyze family bargaining as a dynamic game.

${ }^{8}$ We treat games that take the form of a noncooperative game followed by a repeated game as two-stage games.
} 
required to model the continuing effect of on-the-job skill accumulation on wage rates and future bargaining power. A two-stage game adequately models the once-and-for-all "sheepskin" effect of a college degree on future wage rates and bargaining power.

\section{Bargaining Power}

To operationalize bargaining models requires specifying the empirical counterpart of "bargaining power." For example, in the Nash bargaining model we must specify the variables that determine the threat point. This section discusses three important components of bargaining power: exogenous nonlabor income, wage rates, and productivity in household production.

\subsection{Exogenous Nonlabor Income}

The family bargaining literature has emphasized nonlabor income far beyond its importance in family budgets because of its importance in testing the unitary model. The key insight is that maximizing a family utility function subject to a family budget constraint implies that all family nonlabor income is pooled: lump-sum transfers between spouses that leave a couple's total nonlabor income unchanged have no effect on expenditure patterns or, more generally, on behavior. Tests of the hypothesis that married couples pool their nonlabor income have provided compelling evidence against the unitary model.

The earliest attempts to test the unitary model were not based on pooling, but emerged from traditional demand analysis and were based on the Slutsky conditions. Because the Slutsky conditions are restrictions on the partial derivatives of demand functions, tests based on Slutsky conditions depend critically on functional form 
specification. Hence, any rejection of the unitary model can be attributed to misspecification of the functional form of the demand system rather than to the failure of the unitary model. Revealed preference tests avoid this difficulty because they do not require the specification of a particular functional form, but revealed preference tests lack statistical power.

Recent attempts to test the unitary model have focused on the pooling of nonlabor income. For example, using Brazilian data, Thomas [1990] found that children did better in terms of mortality and morbidity when their mothers controlled a larger fraction of the couple's nonlabor income. Schultz [1990] found that female labor supply in Malaysia was sensitive to which spouse controlled nonlabor income. Both of these studies provide evidence that control over nonlabor income affects behavior -- that is, both studies reject pooling and, hence, reject the unitary model. The Achilles heel of these studies and others that use observed differences across couples in control of nonlabor income is the assumption that nonlabor income is exogenous. For example, if brighter or more energetic wives or wives with a greater labor force attachment are likely to control a larger fraction of the couple's nonlabor income, then the test is confounded. A controlled experiment providing additional resources to husbands in some families and to wives in others would avoid these difficulties. In the absence of controlled experiments, we turn first to a thought experiment and then to a natural experiment.

Lundberg and Pollak [1993] describe a thought experiment that highlights the pooling implications of the unitary model. They consider a child allowance -- a government transfer payment to families with children that is independent of family earnings and income. The thought experiment begins by assuming that initially the child 
allowance is paid to fathers in two-parent families, and then considers the effect of a policy change that switches the payment to mothers. The child allowance provides a transparent example of an exogenous change in control over resources.

Changes in the British child allowance program in the late 1970s provide a natural experiment. The changes, introduced in stages over a two year period, had the effect of transferring substantial resources from husbands to wives in two-parent families. Lundberg, Pollak, and Wales [1997] analyze the effects of these changes on the expenditure patterns of British households, and find that the changes caused a substantial and significant increase in expenditure on children's clothing relative to men's clothing, and on women's clothing relative to men's clothing. Ward-Batts [forthcoming], using disaggregated expenditure data, found that the changes caused a substantial and significant change in the composition of tobacco expenditure: an increase in expenditure on cigarettes, and a decrease in expenditure on cigars and pipe tobacco, which she calls "men's tobacco." The results of the changes in the British child allowance provide evidence against the unitary model by providing convincing evidence against what economists have come to call the "pooling hypothesis."

Because the meaning of "pooling" differs across disciplines, economists, sociologists, and taxation experts sometimes misunderstand one another. For economists pooling is a property of demand functions or demand systems. In nonunitary models, we can write a couple's demand for a particular good as a function of the nonlabor income of the husband, the nonlabor income of the wife, and a vector of wages and other prices. Unitary models are a special case of nonunitary models in which the husband's nonlabor income and the wife's nonlabor income enter only as a sum, so that a transfer of a dollar 
from the husband to the wife does not alter the couple's expenditure pattern. Economists describe such couples as "pooling" their nonlabor income.

For sociologists pooling refers to the way couples manage their money -- for example, whether a couple has one bank account (theirs), two bank accounts (his and hers), or three bank accounts (his, hers, and theirs). Sociologists such as Pahl [1983], Treas [1993] and Zelizer [1989, 1994] find considerable heterogeneity in families' money management practices. It is unclear, however, whether economists should regard such practices as independent variables that can be used to explain differences in expenditure patterns, or as dependent variables that require explanation. Woolley [2003] discusses money management practices and related issues and provides references to the literature.

For academic lawyers who study taxation, pooling refers to the equitable sharing of resources within marriage. McIntyre [1980, 1997] uses the assumption that spouses pool resources in this sense as a rationale for joint taxation (i.e., taxing couples on their total earnings rather than taxing the husband on his earnings and the wife on her earnings). McIntyre's argument appears to require interpreting pooling to mean equal sharing of money income and ignoring leisure, household production, and economies of scale in consumption. Under these assumptions, horizonal equity requires equal taxes for a two-earner couple in which both spouses earn $\$ \mathrm{X}$ and a one-earner couple in which one spouse earns $\$ 2 \mathrm{X}$ and the other $\$ 0$.

Nonlabor income provides a good starting point for discussing the components of bargaining power, but earnings is a far larger fraction of the resources of most couples. Nonlabor income and earnings play very different roles in family bargaining, and the 
differences are not econometric quibbles. I now turn to the roles of earnings and wage rates.

\subsection{Earnings and Wage Rates}

Although some researchers have attempted to test the pooling hypothesis using measures of income that include earnings, such tests are inappropriate for two reasons. ${ }^{9}$ Both reasons are best illustrated in a Nash bargaining framework where the threat point is a noncooperative equilibrium, either divorce or a noncooperative equilibrium within marriage. First, observed earnings -- that is, earnings at the observed cooperative equilibrium -- are a poor proxy for earnings at the unobserved noncooperative equilibrium. The difficulty is exemplified by the stay-at-home spouse. Suppose, for example, a wife does not work in the market at the cooperative equilibrium, but would work in the market at the noncooperative equilibrium; her lack of earnings at the cooperative equilibrium fails to predict her earnings at the noncooperative equilibrium. Hence, even if bargaining power depended on earnings at the noncooperative equilibrium, the wife's earnings at the cooperative equilibrium would fail to predict her bargaining power. $^{10}$

Second, bargaining power does not depend on earnings at the noncooperative equilibrium. In the standard neoclassical model, earnings are the product of hours worked and an individual's wage rate. A decision to allocate more hours to market work (as opposed to leisure) at the noncooperative equilibrium has no determinate effect on bargaining power, but a higher wage rate does translate into greater bargaining power.

\footnotetext{
${ }^{9}$ Lundberg and Pollak [1996] discuss some of these attempts and provide references to the literature.

${ }^{10}$ Instead of using the hourly wage rate, we could equally well use "full-time earnings" -- that is, the hourly wage rate multiplied by a standard number of hours (e.g., 40). But using full earnings is essentially equivalent to using the hourly wage rate and very different from using actual earnings.
} 
Two further complications require acknowledgment. First, if an individual's hourly wage rate depends on the number of hours worked, then well-being at the threat point and, hence, bargaining power, depend on the entire wage schedule. That is, suppose an individual's earnings, $\mathrm{Y}$, are a function of hours worked in the market, $\mathrm{t}_{\mathrm{m}}: \mathrm{Y}=$ $\mathrm{Y}\left(\mathrm{t}_{\mathrm{m}}\right)$. If the earnings function shifts out, so that earnings are greater for every choice of hours worked, $\mathrm{Y}^{*}\left(\mathrm{t}_{\mathrm{m}}\right) \geq \mathrm{Y}\left(\mathrm{t}_{\mathrm{m}}\right)$, for all $\mathrm{t}_{\mathrm{m}}>0$, then well-being at the threat point and, hence, bargaining power will be greater. ${ }^{11}$ Second, if workers acquire human capital on the job, so that hours worked today affect the wage rate tomorrow or, more generally, affect the wage schedule tomorrow, then these human capital effects require a dynamic model. Both of these complications have analogues in the context of household production.

The original divorce threat models of Manser-Brown and McElroy-Horney emphasized the role of market wage rates. The more recent literature on intrafamily allocation has emphasized nonlabor income and child allowances, both as expositional devices and because they lead to empirical tests of the unitary model. An unintended and unfortunate byproduct of this emphasis on nonlabor income and child allowances has been neglect of wage rates and confusion about their role. Having dispelled that confusion, I now consider a richer class of household models in which individuals allocate their time among market work, leisure, and household production.

\subsection{Household Production}

Household production affects the threat point in divorce threat and separate spheres bargaining through different mechanisms. In both divorce threat and separate

\footnotetext{
${ }^{11}$ Neoclassical economics focuses on the special case in which $Y\left(t_{m}\right)=w t_{m}$, where the individual's market wage rate, $\mathrm{w}$, is independent of hours worked. In the neoclassical case, the market wage rate is a sufficient statistic for the earnings function and an increase in $w$ implies that $\mathrm{Y}^{*}\left(\mathrm{t}_{\mathrm{m}}\right) \geq \mathrm{Y}\left(\mathrm{t}_{\mathrm{m}}\right)$ for all $\mathrm{t}_{\mathrm{m}}>0$.
} 
spheres bargaining models, however, once the threat point is specified the calculation of the cooperative equilibrium and the corresponding allocation of goods and time is conceptually straightforward.

In divorce threat bargaining, the threat point depends on the technologies available to the spouses individually following divorce. Thus, a spouse who has low productivity in household production (e.g., because he or she lacks the requisite human capital) will be disadvantaged in bargaining within marriage unless (a) the goods market offers satisfactory substitutes for the outputs of household production or (b) the economic and psychological costs of divorce are small, and remarriage offers the prospect of readily finding a new spouse whose household production skills replace those of the current spouse.

In separate spheres bargaining, the threat point depends on the technologies available to the spouses in a noncooperative marriage. Separate spheres bargaining is more complicated than the divorce threat bargaining in two respects. First, in separate spheres bargaining to calculate the threat point requires specifying not only the technology available to the couple in a noncooperative marriage but also specifying the noncooperative game they play. In that noncooperative game, each spouse presumably allocates his or her own time among three activities, \{market labor, household production, and leisure\}, and allocates his or her own resources, \{nonlabor income + earnings\}, between private consumption and expenditures on inputs into household production. Second, in separate spheres bargaining the reservation utilities and the threat point are distinct. The reservation utilities require no additional discussion because they coincide with the threat point in divorce threat bargaining. 
Greater productivity in household production gives an individual greater bargaining power. More precisely, an outward shift in the production frontier, indicating that greater output is obtainable from every combination of inputs, implies greater bargaining power. An outward shift in the production frontier is analogous to an outward shift in the earnings function.

The repeated game in which spouse play a one-shot household production game over and over as a stage game allows punishment much as the repeated voluntary contribution game of Lundberg and Pollak [1994] allows punishment. Embedding household production in a repeated game provides a Coasian rationale for the belief that family bargaining leads to efficient outcomes. The folk theorem guarantees that, provided family members are sufficiently patient, every individually-rational allocation is a subgame perfect equilibrium. The folk theorem, however, does not address the problem of equilibrium selection or imply that the equilibrium will be Pareto efficient. The assumption that the stage game remains unchanged from one period to the next is also problematic. Time allocation in one period may affect human capital in subsequent periods: just as the wage rate may depend on past labor supply, productivity in household production may depend on past household production.

Punishment always raises issues of credibility. At the threat point in separate spheres bargaining with household production, each spouse is likely to hold back inputs into the production of household public goods and private goods that enter the utility function of the other spouse. Such behavior is analogous to holding back voluntary contributions to the purchase of household public goods in separate spheres bargaining without household production. The scope for a "slow down" or "strike" in the production 
of private goods that enter the utility function of the other spouse may be greater than in the production of household public goods because the spouse producing the public goods also consumes them. That is, withholding private goods that benefit only the other spouse (e.g., toast) is more credible than withholding public goods (e.g., neglecting the children). Nancy Folbre [2001], in her book, The Invisible Heart, makes this point, suggesting that a spouse who engages in "caring labor" may become a "prisoner of love" unwilling to withhold household production. ${ }^{12}$

\section{Tax Systems}

Before discussing the role of taxes in bargaining models of marriage, I need to describe the tax treatment of married couples under alternative tax systems. I assume that "marriage" is well-defined for tax purposes, without reaching the question of how it is defined (e.g., whether the tax code treats heterosexual cohabiting couples as married; whether same-sex couples are allowed to marry). To simplify the discussion, I restrict myself to the taxation of earnings, recognizing that this restriction is somewhat odd in the light of the importance of nonlabor income in the analysis of pooling. I also assume that taxes are independent of the pattern of consumption expenditures (e.g., mortgage interest payments are not deductible.)

I focus on three types of taxation of married couples: "individual taxation" ("separate filing"), "joint taxation," ("joint filing"), and "hybrid taxation" which includes as special cases both individual and joint taxation. I denote the tax schedule facing unmarried individuals by $\mathrm{T}^{\mathrm{u}}(\mathrm{y})$ and the tax schedule facing married couples $\mathrm{T}^{\mathrm{m}}\left(\mathrm{y}, \mathrm{y}^{\prime}\right)$.

\footnotetext{
${ }^{12}$ Medea, to revenge herself on her husband Jason, killed their joint children, but she is generally regarded as a poor role model.
} 
Definition: An elementary tax system is a specification of

$$
\mathrm{T}^{\mathrm{u}}(\mathrm{y}) \text { and } \mathrm{T}^{\mathrm{m}}\left(\mathrm{y}, \mathrm{y}^{\prime}\right)
$$

I consider only sex-neutral tax systems, that is, tax systems in which $\mathrm{T}^{\mathrm{u}}(\mathrm{y})$ independent of sex of taxpayer and $\mathrm{T}^{\mathrm{m}}\left(\mathrm{y}, \mathrm{y}^{\prime}\right)=\mathrm{T}^{\mathrm{m}}\left(\mathrm{y}^{\prime}, \mathrm{y}\right)$.

Definition: A tax schedule facing married couples of the form

$$
\mathrm{T}^{\mathrm{m}}\left(\mathrm{y}, \mathrm{y}^{\prime}\right)=\mathrm{T}^{\mathrm{o}}(\mathrm{y})+\mathrm{T}^{\mathrm{o}}\left(\mathrm{y}^{\prime}\right)
$$

is called individual taxation.

Definition: A tax schedule facing married couples of the form

$$
\mathrm{T}^{\mathrm{m}}\left(\mathrm{y}, \mathrm{y}^{\prime}\right)=\mathrm{T}^{\mathrm{oo}}\left(\mathrm{y}+\mathrm{y}^{\prime}\right)
$$

is called joint taxation.

That is, with individual taxation each spouse's marginal tax rate is independent of the earnings of the other spouse, while with joint taxation spouses pay the same marginal tax rate and a couple's tax liability depends only on the sum of their earnings. Individual taxation of married couples does not preclude a marriage penalty: the tax schedule facing a married individual, $\mathrm{T}^{\mathrm{O}}(\mathrm{y})$, need not be the same as the tax schedule facing an unmarried individual, $\mathrm{T}^{\mathrm{u}}(\mathrm{y})$.

Definition: A tax schedule facing married couples of the form

$$
\mathrm{T}^{\mathrm{m}}\left(\mathrm{y}, \mathrm{y}^{\prime}\right)=\sigma^{*}\left[\mathrm{~T}^{*}(\mathrm{y})+\mathrm{T}^{*}\left(\mathrm{y}^{\prime}\right)\right]+\sigma^{* *} \mathrm{~T}^{* *}\left(\mathrm{y}+\mathrm{y}^{\prime}\right)
$$

is called hybrid taxation.

Hybrid taxation contains as special cases both individual taxation of married couples $\left(\sigma^{*}=1, \sigma^{* *}=0\right)$ and joint taxation $\left(\sigma^{*}=0, \sigma^{* *}=1\right)$. Hybrid taxation is interesting for at least two reasons. First, although the U.S. tax system is often described as joint taxation, capped payroll taxes make it a hybrid. Joint taxation is consistent with a 
proportional payroll tax with no cap, $\mathrm{T}^{*}(\mathrm{y})=\mathrm{t}^{*} \mathrm{y}$, but not with a proportional payroll tax with a cap at $\mathrm{T}^{*}(\mathrm{y})=\min \left\{\mathrm{t}^{*} \mathrm{y}, \mathrm{t}^{*}\right\}$. The U.S. social security tax is a payroll tax with a cap and many couples pay more in social security taxes than in income tax.

Second, hybrid taxation is a weighted sum of individual and joint taxation. Although attention has generally focused on the polar cases of individual taxation and joint taxation, the intermediate cases are interesting and, from the standpoint of optimal income taxation, may be superior to either extreme. Nevertheless, I focus on the polar cases of individual and joint taxation because they exemplify key features of the role of taxes in family bargaining.

I assume that couples are offered a choice between joint filing and a default tax schedule, $T^{\mathrm{d}}(\mathrm{y})$, (e.g., "married, filing separately") that depends only on each spouse's individual earnings. In separate spheres bargaining the default tax schedule enables spouses to calculate their well-being in the noncooperative equilibrium, that is, at the threat point. I assume that the default schedule entails a total tax liability for a couple that is greater than or equal to their liability with joint filing. For at least some couples -for many couples, if joint taxation has any bite -- the default tax schedule entails total taxes for the couple strictly greater than with joint filing. In the U.S. married couples who use the default schedule "married, filing separately" almost never have a lower total tax liability than if they had filed jointly; many couples that file separately do so to avoid joint and several liability. ${ }^{13}$

Definition: A tax system is a specification of three schedules:

$$
\mathrm{T}^{\mathrm{u}}(\mathrm{y}), \mathrm{T}^{\mathrm{m}}\left(\mathrm{y}, \mathrm{y}^{\prime}\right) \text {, and } \mathrm{T}^{\mathrm{d}}(\mathrm{y})
$$

\footnotetext{
${ }^{13}$ Under joint and several liability, each spouse is individually responsible for the couple's entire tax obligation; i.e., the government can collect the entire amount from one spouse. Having paid the government, the paying spouse may then sue the nonpaying spouse to force a contribution.
} 
That is, a tax system is an elementary tax system together with a default tax schedule. With individual taxation of married couples, a default tax schedule is unnecessary because the individual tax schedule facing a married individual, $\mathrm{T}^{\mathrm{o}}(\mathrm{y})$, enables spouses to calculate their well-being in the noncooperative equilibrium; that is, with individual taxation the default tax schedule coincides with the individual tax schedule.

I do not consider tax systems that offer married couples the option of joint filing or separate filing using a tax schedule that, for some couples, would reduce their total tax liability. Such a system -- perhaps offering married couples the option of joint filing or filing as if they were unmarried individuals -- would make joint filing optional rather than mandatory. Such a system of optional joint filing would eliminate the marriage penalty while leaving open the possibility that some couples might enjoy a marriage bonus. ${ }^{14}$

\section{Taxes in Bargaining Models}

Taxes affect outcomes because they affect feasible sets, reservation utilities, and bargaining power. I begin with feasible sets and reservation utilities, which do not differ across all bargaining models, and then turn to threat points and bargaining power which differ from one model to another. I then discuss taxes in Becker's altruist model and in the two leading bargaining models: divorce threat and separate spheres. Finally, I briefly discuss two-stage games and repeated games.

A married couple's utility possibility set depends on the tax system in the obvious way. The tax schedule facing couples, together with the spouses' wage rates, other prices,

\footnotetext{
${ }^{14}$ According to Alm and Melnik [2005], six European countries, including Germany, allow couples to choose between joint filing and separate filing.
} 
and the household's technology determine the feasible set facing the household. A vector of market goods and a time allocation vector -- a vector which specifies each spouse's allocation of time among market work, household production, and leisure -either violates or satisfies this feasibility constraint. The utilities corresponding to the set of feasible goods and time vectors constitute the utility possibility set.

Reservation utilities - almost always assumed to be the utilities corresponding to divorce -- also depend on the tax system in the obvious way. The tax schedule facing unmarried individuals, together with the individual's wage rate, preferences, and the technology available to the divorced individual determine his or her utility in the event of divorce.

For threat points and bargaining power, the relevant aspect of the tax system differs from one bargaining model to another. With divorce threat bargaining, the relevant tax schedule is $\mathrm{T}^{\mathrm{u}}(\mathrm{y})$, the schedule facing unmarried individuals. Because the threat point coincides with the reservation utilities, its calculation raises no new issues. With separate spheres bargaining, the threat point depends on whether the tax system requires married couples to file separately or jointly. In both divorce threat and separate spheres bargaining, the threat point depends on the tax schedule required to calculate each spouse's taxes in the noncooperative equilibrium. With joint or hybrid taxation, the relevant tax schedule is the default schedule, $\mathrm{T}^{\mathrm{d}}(\mathrm{y})$. With separate filing, the relevant tax schedule is the individual tax schedule, $\mathrm{T}^{\mathrm{O}}(\mathrm{y})$.

This discussion of feasible sets, reservation utilities, and threat points provides a starting point for comparing alternative tax systems (e.g., joint taxation and individual taxation). In Becker's altruist model, joint taxation affects allocation in ongoing 
marriages only through its effect on the feasible set. Reservation utilities depend on the tax schedule facing unmarried individuals and thus are unaffected by whether married couples face individual or joint taxation. Joint taxation, to the extent that it implies high marginal tax rates on secondary earners, provides incentives for specialization. In the altruist model, however, the distributional effect of one spouse specializing in the market and the other in the home is indeterminant. Thus, in the standard, static version of the altruist model, the claim that joint taxation disadvantages secondary earners in ongoing marriages is false. If the primary earner is the altruist, then the secondary earner's bargaining power is not weakened by joint taxation because she has none: regardless of the tax system, the altruistic primary earner has a monopoly on bargaining power.

With divorce threat bargaining joint taxation affects allocation in ongoing marriages only through its effect on the feasible set. The reservation utility/threat point depends only on the tax schedule facing unmarried individuals. As in the altruist model, joint taxation provides incentives for specialization but in static divorce threat bargaining the distributional effect of joint taxation, which operate through the feasible set, is indeterminant.

With static separate spheres bargaining and "rational" neoclassical spouses, joint taxation affects allocation in ongoing marriages only through its effect on the feasible set. The reservation utilities depend only on the tax schedule facing unmarried individuals, and the threat point depends only on the default tax schedule. Thus, with static separate spheres bargaining and rational neoclassical spouses, the joint tax schedule does not affect the threat point. 
Three dynamic qualifications require mention. First, in all three models, spouses who fail to accumulate human capital will be disadvantaged in terms of reservation utilities. But reservation utilities affect allocation in marriage only for couples at "corner solutions" in which one spouse is indifferent between divorce and remaining in the marriage. Second, in all three models, spouses who fail to accumulate human capital will be disadvantaged in the event of divorce. ${ }^{15}$ Third, with divorce threat and separate spheres bargaining, but not in the altruist model, bargaining power within marriage depends on wage rates; hence, spouses who fail to accumulate market human capital will be disadvantaged in future bargaining. These three dynamic qualifications underscore the importance of market human capital, but the dynamic issues are more complicated than this paragraph suggests.

Complications arise because rational, forward-looking spouses recognize these dynamic human capital effects. Only naive, myopic spouses ignore the effects of their current behavior on their future bargaining power. To analyze these dynamic effects requires modeling bargaining within marriage as a dynamic game. Two-stage games, the simplest dynamic games, are suitable for modeling the effect of a high school or college degree on future wage rates and bargaining power. More complex dynamic games are required for modeling the on-going effects of work experience (e.g., learning-by-doing) on wage rates and bargaining power.

\footnotetext{
${ }^{15}$ This statement is true unless spouses have prenuptial agreements, or unless courts compensate ex-spouses for their failure to accumulate human capital. If courts do compensate, then the expectation of compensation affects incentives to accumulate human capital before and during marriage.
} 


\section{Extensions}

In this section I briefly discuss three extensions that deserve more thorough analysis. First, behavioral economists might suggest that spouses are not rational neoclassical agents and that actual earnings, not just wage rates, affect bargaining power. An extreme version of this suggestion is the claim that bargaining power depends on actual earnings and is independent of wage rates. The two remaining extensions move beyond bargaining in particular marriages to the equilibrium effects of taxation. I first consider the effects on marriage market equilibrium -- who marries, and who marries whom -- and then the effects on labor market equilibrium.

Behavioral economics provides a rationale for recognizing a role for actual earnings in family bargaining, either instead of or in addition to wage rates. Perhaps spouses maintain "mental accounts" that relate consumption by each spouse to that spouse's actual earnings. Such mental accounts might be associated with and reinforced by money management systems in which spouses maintain separate credit cards or bank accounts. $^{16}$ If actual earnings affect bargaining power, then the allocation of time to market work presumably reflects the effect of earnings on bargaining power as well as the familiar trade offs among market work, leisure, and household production. Thus, whatever the advantages of treating actual earnings as a determinant of bargaining power, analytical simplicity is not among them.

Taxes further complicate the earnings story. Bargaining power presumably depends on after-tax earnings, but with joint taxation, after-tax earnings are not welldefined. To map before-tax earnings into after-tax earnings requires an imputation of the

\footnotetext{
${ }^{16}$ On behavioral economics, see Kahneman [2003]; on mental accounting, see Thaler [1985, 1999]; on money management, see Woolley [2003].
} 
spouses' joint tax liability, and such imputations are inevitably somewhat arbitrary. McCaffery [1997] suggests that couples themselves impute their joint tax liability as well as certain other expenses such as child care in ways that disadvantage women. Thus, a behavioral story about earnings must be supplemented by a behavioral story about taxes.

The tax withholding schedule appears to offer a solution analogous to that provided by the default tax schedule. The default tax schedule might coincide with the withholding tax schedule, $\mathrm{T}^{\mathrm{w}}(\mathrm{y})$, but usually these two schedules are distinct. In an interesting review of McCaffery's book, Woolley [1999] interprets McCaffery as claiming that take-home pay matters for family bargaining. She points out that if it does, then the mechanics of withholding must play a crucial role, and criticizes McCaffery for failing to discuss withholding. Regardless of whether we interpret McCaffery as implying the importance of withholding, those who make behavioral arguments for earnings cannot easily dismiss extensions that interpret earnings as take-home pay and, hence, emphasize the role of withholding. Woolley is surely right that the mechanics of withholding deserve more attention.

Despite its superficial attractiveness, however, the analogy between the default tax schedule and the withholding schedule has two weaknesses. First, take-home pay and after-tax earnings differ. The total amount withheld for taxes seldom equals a couple's tax liability: some couples owe taxes at the end of the year, while others receive refunds. From a modeling standpoint, we require assumptions about when couples recognize the disparity between the amount withheld and their tax liability, and how they deal with it. Second, withholding is not determined by an inflexible schedule: individuals exercise some control over the amount withheld. Hence, if take-home pay is a source of 
bargaining power, spouses may exploit the flexibility in the withholding rules to advantage themselves in family bargaining.

Behavioral economists might reject the claim that bargaining power depends on wage rates and the default tax schedule, arguing that the claim assumes that spouses are hyperrational economic agents with an implausibly sophisticated understanding of the tax system. For less rational or less sophisticated spouses might bargain on the basis of the withholding schedule instead of the default tax schedule because they believe the withholding schedule is the default tax schedule. I find the argument of the behavioral economist fairly persuasive, but the issue is empirical.

Because prospective spouses decide whether to marry by comparing their wellbeing as unmarried individuals with their well-being married to each other, the taxation of unmarried individuals and married couples has marriage market effects. In the U.S., some couples pay a marriage penalty while others receive a marriage bonus. Two-earner couples with equal earnings pay the largest penalties, while one-earner couples receive the largest bonuses. Economics teaches that couples that would incur marriage penalties are less likely to get married and stay married, while couples that receive marriage bonuses are more likely to do so. Alm, Dickert-Conlin, and Whittington [1999] describe the marriage penalties and bonuses contained in the U.S. tax system, and discuss the empirical literature on the effects of taxes on marriage. ${ }^{17}$

Economists have two approaches to modeling competition and equilibrium in marriage markets, one based on matching and the other on search. Both approaches

\footnotetext{
${ }^{17} \mathrm{~A}$ tax system that affects marriage may also affect outcomes for children. For example, descriptive statistics show that children are more likely to graduate from high school if their parents are married and remain married. Ginther and Pollak [2004] summarize this literature and argue that whether the correlations between family structure and outcomes for children reflect causal relationships is an open question.
} 
begin with individual preferences, but they make different assumptions about the information available to and the alternatives faced by marriage-market participants. Matching models are nonstochastic and timeless; they implicitly assume that complete and accurate information about all potential spouses is instantaneously and costlessly available to every marriage-market participant. Search models, in contrast, are stochastic and dynamic; they recognize explicitly that individuals have less than complete and accurate information about potential spouses, and that acquiring more and better information requires resources and takes time; search models often emphasize the role of impatience or, more formally, positive time preference. ${ }^{18}$

Because some couples suffer a marriage penalty and others receive a marriage bonus, the tax system affects not only who marries, but who marries whom. Using a search model, together with specific assumptions about the nature of the gains to marriage and the division of the surplus within marriage, Chade and Ventura [2002] perform a simulation to examine the effect of the U.S. tax system on marriage, assortative mating, and labor supply. ${ }^{19}$ They carefully specify three alternatives to the present U.S. tax system, each of which generates the same revenue, and use these for comparison purposes. Perhaps not surprisingly, their results are sensitive to which alternative tax system they consider, but for all three alternatives they find that eliminating the marriage penalty increases the labor supply of married women. The effects on marriage formation and on assortative mating, however, depend on which alternative tax system they consider.

\footnotetext{
${ }^{18}$ Much of this paragraph is shamelessly lifted from Pollak [2000].

${ }^{19}$ Although their simulation is complex, it includes neither household production nor human capital.
} 
An analysis of taxation that considers only the effects on a particular married couple is equivalent to investigating an experimental tax system that applies only to a tiny fraction of the population. Such a partial analysis is a crucial first step toward understanding the effects of taxation on marriage, but it is only a first step. The next step is to analyze the effects of a fully-implemented tax system that applies to everyone. Tax systems that apply to everyone have equilibrium effects that cannot be inferred directly from the effects of the experimental version. ${ }^{20}$ To the extent the tax system affects individuals' decisions to marry, it will have equilibrium effects that operate through the marriage market. To the extent that the tax system affects individuals' labor supply and human capital investments, it will have equilibrium effects that operate through the labor market and the market for human capital.

Equilibrium labor market effects of taxation may differ substantially from effects in particular marriages. We begin, of course, by assuming that individuals take wage rates as given and adjust their labor supply in response to the incentives created by the tax system, but individuals' labor supply adjustments affect wage rates. Similarly, individuals take the returns to human capital as given and adjust their investments in response to the tax system, but their investments affect both the returns to human capital and the cost of acquiring human capital. The effects of taxation on marriage market and labor market equilibrium, however, are beyond the scope of this paper.

\footnotetext{
${ }^{20}$ This distinction between experimental and implementation versions is equivalent to a distinction emphasized by Heckman, Lochner, and Taber [1998] in their discussion of the effects of tuition subsidies. To the extent that tuition subsidies induce individuals to attend college, they will affect educational attainment, but they will also effect the equilibrium wage rates of those who attend college and those who do not; Heckman, Lochner, and Taber argue that the experimental and the implementation effects of tuition subsidies differ by an order of magnitude.
} 


\section{Conclusion}

An answer to the question, "Does joint taxation disadvantage women?" implies both a counterfactual -- an alternative tax system to compare with joint taxation -- and assumptions about the extent to which individuals and markets adjust. In this paper, I have focused on the behavior of individuals and couples, leaving to another paper the task of analyzing market equilibrium. The importance of this limitation is obvious. Individuals and couples take wage rates as given and adjust their labor supply, but labor supply adjustments affect equilibrium wage rates. Similarly, tax-induced changes in the willingness of individuals to marry affect marriage market equilibrium -- who marries, and who marries whom. Finally, individuals and couples take the returns to human capital as given and adjust their investments, but their investment decisions affect the returns to human capital. Nevertheless, the behavior of individuals and couples is the right place to begin.

Two polar assumptions bracket the range of adjustment possibilities for individuals and couples. The minimal adjustment holds fixed most behavior (e.g., labor supply, marital status, and human capital), allowing adjustment of expenditures on goods, of the allocation of time between leisure and household production and, for couples, of the allocation of consumption between spouses. The maximal adjustment holds fixed only preferences, technology, and endowments. We could interpret various partial adjustments (e.g., labor supply adjusts, but marital status and human capital are held fixed) as alternative short runs and the maximal adjustment as the long run. These interpretations are misleading, however, because they ignore the extent to which markets 
(e.g., labor markets, marriage markets, and markets for human capital) are assumed to adjust.

The separate spheres bargaining model has emphasized exogenous nonlabor income (e.g., child allowances) because the pooling of exogenous income provides a test of the unitary model. But separate spheres bargaining models have deemphasized, indeed virtually ignored, earnings and wages. Because earnings are the principal source of income for most individuals and couples, and because taxes fall primarily on earnings, a family bargaining model that ignores earnings and wages does not provide a good starting point for the analysis of taxation. To analyze the responses of individuals and couples to alternative tax systems, I have sketched a family bargaining model that recognizes not only the role of exogenous nonlabor income but also wage rates and productivity in household production.

Joint taxation complicates separate spheres bargaining but not divorce threat bargaining. In separate spheres bargaining, the threat point is internal to the marriage and depends on assumptions about the noncooperative game that determines the threat point. A default tax schedule (e.g., "married, filing separately") enables spouses to make the noncooperative labor supply decisions that underlying the separate spheres threat point. In divorce threat bargaining, on the other hand, the threat point is external to the marriage and, hence, is unaffected by the tax schedule facing married couples.

In the absence of human capital effects, joint taxation does not appear to disadvantage women in either divorce threat or separate spheres bargaining. Hence, McCaffery's claim that joint taxation disadvantages women, if it is correct, depends on effects that operate through the incentives to accumulate human capital. But a 
satisfactory analysis of the effects of taxation on human capital awaits the further development of dynamic models of family bargaining. 


\section{References}

Alm, James, Stacy Dickert-Conlin, and Leslie A. Whittington, "The Marriage Penalty," Journal of Economic Perspectives, Vol. 13, No. 3, (Summer 1999), 193-204.

Alm, James and Mikhail I. Melnik, "Taxing the 'Family' in the Individual Income Tax" Public Finance and Management, Vol. 5, No. 1 (2005), 67-109.

Apps, Patricia F. and Ray Rees, "Taxation of Couples" (July 2007). IZA Discussion Paper No. 2910

Arrow, Kenneth J., "A Difficulty in the Concept of Social Welfare," Journal of Political Economy, Vol. 58, No. 4, (August 1950), 328-346.

Arrow, Kenneth J., Social Choice and Individual Values, Cowles Foundation for Research in Economics, New York: Wiley, 1st ed., 1951, 2nd ed., 1963.

Aura, Saku, "Uncommitted Couples: Some Efficiency and Policy Implications of Marital Bargaining" Manuscript, University of Missouri, 2007.

Becker, Gary S., Treatise on the Family, Cambridge: Harvard University Press, 1981; Enlarged edition, 1991.

Bergstrom, Theodore C., "Economics in a Family Way," Journal of Economic Literature, Vol. XXIV, No. 4, (December 1996), 1903-1934.

Chade, Hector and Gustavo Ventura, "Taxes and Marriage: A Two-sided Search Analysis," International Economic Review, Vol. 43, No. 3, (August 2002), 955-985.

Chiappori, Pierre-André, "Rational Household Labor Supply," Econometrica, Vol. 56, No. 1, (January 1988), 63-89.

Chiappori, Pierre-André, "Collective Labor Supply and Welfare," Journal of Political Economy, Vol. 100, No. 3, (June 1992), 437-467.

Folbre, Nancy, The Invisible Heart: Economics and Family Values, New York: The New Press, 2001.

Ginther, Donna K. and Robert A. Pollak, "Family Structure and Children's Educational Outcomes: Blended Families, Stylized Facts, and Descriptive Regressions," Demography, Vol. 41, No. 4, (November 2004), 671-696.

Gugl, Elisabeth, "Joint vs. Individual Taxation and Intrafamily Distribution," University of Victoria Working Paper, January 2004. 
Heckman, James J., Lance Lochner, and Christopher Taber, "General Equilibrium Effects: A Study of Tuition Policy," American Economic Review, Vol. 88, No. 2, (May 1998), 293-297.

Kahneman, Daniel, "Maps of Bounded Rationality: Psychology for Behavioral Economics," American Economic Review, Vol. 93, No. 5, (December 2003), 1449-1475.

Kalai, Ehud and Meir Smorodinsky, "Other Solutions to Nash's Bargaining Problem," Econometrica, Vol. 43, No. 3, (May 1975), 513-518.

Konrad, Kai A. and Kjell Erik Lommerud, "The Bargaining Family Revisited," Canadian Journal of Economics, Vol. 33, No. 2, (May 2000), 471-487.

Lich-Tyler, Stephen, "Negotiations and Love Songs: The Dynamics of Bargained Household Decisions." Unpublished manuscript, Department of Economics, Instituto Tecnológico Autónomo de México, 2004.

Lundberg, Shelly, "Limits to Specialization: Family Policy and Economic Efficiency," June 2002. IZA Conference

Lundberg, Shelly and Robert A. Pollak, "Separate Spheres Bargaining and the Marriage Market," Journal of Political Economy, Vol. 101, No. 6, (December 1993), 988-1010.

Lundberg, Shelly and Robert A. Pollak, "Noncooperative Bargaining Models of Marriage," American Economic Review Vol. 84, No. 2, (May 1994), 132-137.

Lundberg, Shelly and Robert A. Pollak, "Bargaining and Distribution in Marriage," Journal of Economic Perspectives, Vol. 10, No. 4, (Fall 1996), 139-158.

Lundberg, Shelly and Robert A. Pollak, "Efficiency in Marriage," Review of Economics of the Household, Vol. 1, No. 3, (September 2003), 153-168.

Lundberg, Shelly, Robert A. Pollak, and Terence J. Wales, "Do Husbands and Wives Pool Their Resources? Evidence from the U.K. Child Benefit," Journal of Human Resources, Vol. 32, No. 3, (Summer 1997), 463-480.

Manser, Marilyn and Murray Brown, "Marriage and Household Decision-Making: A Bargaining Analysis," International Economic Review, Vol. 21, No. 1, (February 1980), 31-44.

McCaffery, Edward J., Taxing Women, Chicago: University of Chicago Press, 1997.

McElroy, Marjorie B. and Mary J. Horney, "Nash-Bargained Household Decisions: Toward a Generalization of the Theory of Demand," International Economic Review, Vol. 22, No. 2, (June 1981), 333-349. 
McIntyre, Michael J., "Individual Filing in the Personal Income Tax: Prolegomena to Future Discussion," North Carolina Law Review, Vol. 58, No. 3, (1980), 469-489.

McIntyre, Michael J., Review of Taxing Women by Edward J. McCaffery, National Tax Journal, Vol. 50, No. 4, (December 1997), 819-826.

Messere, Ken, ed., The Tax System in Industrialized Countries, New York: Oxford University Press, 1998.

Nash, John F., "The Bargaining Problem," Econometrica, Vol 18, No. 1, (April 1950), 155-162.

Pahl, Jan, "The Allocation of Money and the Structuring of Inequality within Marriage," Sociological Review, Vol 31, No. 2, (May 1983), 237-262.

Pezzin, Liliana, Robert A. Pollak, and Barbara S. Schone, "Efficiency in Family Bargaining: Living Arrangements and Caregiving Decisions of Adult Children and Disabled Elderly Parents" CESifo Economic Studies, Vol. 53, No. 1, (March 2007), 69-96.

Pollak, Robert A., "Tied Transfers and Paternalistic Preferences," American Economic Review, Vol. 78, No. 2, (May, 1988), 240-244.

Pollak, Robert A., "Theorizing Marriage," in Linda Waite, Christine Bachrach, Michelle Hindin, Elizabeth Thomson, and Arland Thornton, eds. Ties that Bind: Perspectives on Marriage and Cohabitation. New York: Aldine de Gruyter, 2000, 111-125.

Pollak, Robert A., "Gary Becker's Contributions to Family and Household Economics," Review of Economics of the Household, Vol. 1, No 1-2, (January-April 2003), 111-141.

Pollak, Robert A., "Bargaining Power in Marriage: Earnings, Wage Rates and Household Production" NBER Working Paper 11239, March 2005.

Samuelson, Paul A., "Social Indifference Curves," Quarterly Journal of Economics, Vol. 70, No. 1, (February 1956), 1-22.

Schultz, T. Paul, "Testing the Neoclassical Model of Family Labor Supply and Fertility," Journal of Human Resources, Vol. 25, No. 4, (Fall 1990), 599-634.

Shubik, Martin, "Cooperative Games," in The New Palgrave, Game Theory, ed. by John Eatwell, Murray Milgate, and Peter Newman, New York: W.W. Norton, 1989, 103-107.

Stone, Lawrence, Road to Divorce: England 1530-1987, Oxford: Oxford University Press, 1990.

Thaler, Richard H., "Mental Accounting and Consumer Choice," Marketing Science, Vol. 4, No. 3, (Summer 1985), 199-214. 
Thaler, Richard H., "Mental Accounting Matters," Journal of Behavioral Decision Making, Vol. 12, No. 3, (September 1999), 183-206.

Thomas, Duncan, "Intra-Household Resource Allocation: An Inferential Approach," Journal of Human Resources, Vol. 25, No.4, (Fall 1990), 635-664.

Treas, Judith, "Money in the Bank: Transaction Costs and the Economic Organization of Marriage," American Sociological Review, 58, No. 5, (October 1993), 723-734.

Ward-Batts, Jennifer, Out of the Wallet and into the Purse: Modeling Family Expenditures to Test Income Pooling,” Journal of Human Resources (forthcoming).

Woolley, Frances, "A Non-cooperative Model of Family Decision Making," Manuscript. London: London School of Economics, 1988.

Woolley, Frances, "Edward J. McCaffery, Taxing Women," Feminist Economics, Vol. 5, No. 1, (March 1999), 126-130.

Woolley, Frances, "Control over Money in Marriage," in Marriage and the Economy: Theory and Evidence from Advanced Industrial Societies, ed. by Shoshana GrossbardShechtman, Cambridge: Cambridge University Press, 2003, 105-128.

Zelizer, Viviana A., "The Social Meaning of Money: 'Special Monies'," American Journal of Sociology, Vol. 95, No. 2, (September 1989), 342-377.

Zelizer, Viviana A. The Social Meaning of Money, New York: Basic Books, 1994. 